The Israeli Journal of Aquaculture - Bamidgeh IJA.73.2021.1434765, 16 pages

CCBY-NC-ND-4.0 • https://doi.org/10.46989/001c.28235

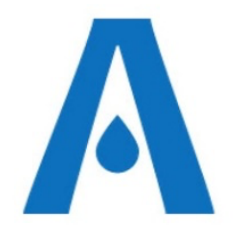

The IJA is a peer-reviewed open-access, electronic journal, freely available without charge to users

Produced by the AquacultureHub non-profit Foundation Sale of IJA papers is strictly forbidden

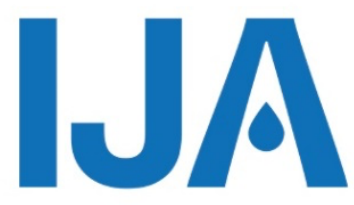

\title{
Induced spawning and larval rearing of the sea cucumber Holothuria nobilis
}

\author{
Hung Van Nguyen', Bakari Ahsadi Mariamu1, 2, Hung Quoc Pham 3* \\ ${ }^{1}$ Research Institute for aquaculture No. 3, Nha Trang, Vietnam \\ 2 Sokoine University of Agriculture, Morogoro, Tanzania \\ ${ }^{3}$ Institute of Aquaculture, Nha Trang University, Nha Trang, Vietnam
}

Key words: Teat fish, larviculture, mariculture, sea cucumber, induced spawning

\begin{abstract}
Sea cucumber Holothuria nobilis is an economically important species for livelihoods in many countries. However, an increase in demand for this species has led to the depletion of wild stocks. The introduction of this species in aquaculture is necessary to reduce fishing pressure. This study was taken to establish breeding and larval rearing techniques for the development of $H$. nobilis aquaculture. The broodstock collected from the wild were induced to spawn by using thermal stimulation and the combination of thermal and algal stimulation methods. The larvae obtained from induced spawning were reared using different diets (mixed microalgae and mixed microalgae with artificial feeds) at different stocking densities (300, 600, and 1000 larvae/I). Thermal stimulation is the best method of inducing spawning to $H$. nobilis yielding up to $1,300,000$ fertilized eggs. The highest survival rate $(27.5 \%)$ of doliolaria larvae was achieved using a mixed microalgae diet. The highest survival rate of doliolaria larvae $(41.5 \%)$, growth, and development were in the stocking density of 600 larvae/l.
\end{abstract}

* Corresponding author. Tel: +84 1653757898; e-mail: phamquochung@ntu.edu.vn 


\section{Introduction}

Sea cucumbers are marine invertebrates with leathery skin and an elongated body containing one or branched gonad (Kinch et al., 2008). Sea cucumber provides a crucial role within the aquatic ecosystem as deposit feeders filtering ocean sediments and recycling nutrients back to the food cycle (Maria del Mar Otero Villanueva, 2005). Holothuria nobilis is one of the highly nutritional, medicinal, and commercial value sea cucumber species found in Vietnam and other tropical and subtropical countries (Wen et al.,2010). The rising demand for $\mathrm{H}$. nobilis markets in Asia has led to overexploitation, including unmatured ones, and this resulting the depletion of the natural sea cucumber population around the world (Purcell et al., 2012). However, Holothurian populations take a long time to recover, and some studies show that it may take up to 50 years without any fishing pressure to allow the populations of sea cucumbers in the overexploited area to recover (Bruckner et al., 2003). Hence $H$. nobilis has been categorized as endangered species (Abidin et al., 2019). Therefore, management programs of this species, such as aquaculture, are necessary to overcome wild exploitation.

The technology for culturing sea cucumber has advanced in recent years. Chinese and Japanese are pioneers in the aquaculture of the sea cucumber. They developed hatchery technology for Apostichopus japonicus and Holothuria scabra followed by India on farming of Holothuria scabra (James, 2004). Recently Vietnam has progressively developed a viable aquaculture production of sea cucumbers (Holothuria scabra and Actinopyga echinites). The output of $H$. scabra, has succeeded, whereby the animals gained an average weight of $40-$ $60 \mathrm{~g}$ per month (Dinh, 2017).

The development of hatchery technology for the thriving culture of sea cucumbers requires proper knowledge of inducing spawning and larvae rearing protocols such as feeding and stocking density (Slater et al., 2009). The high stocking density of sea cucumber larvae reduce available space and food, causing malnutrition, poor development, growth, and survival rate (Asha and Diwakar, 2013). While improper feeding results in the poor growth, development, and survival rate of sea cucumber larvae (Asha and Diwakar, 2013). Up to very recently, the knowledge of inducing spawning and larval rearing of ( $H$. nobilis) being still unknown, the assessment of inducing spawning methods and larvae rearing technique is of vital concern for the successful production of $H$. nobilis in the hatchery. Findings from this study help to establish a baseline for the development of its breeding program and aquaculture production for the sea ranching, restocking, and improving the livelihoods of the farming communities.

\section{Study area}

\section{Materials and Methods}

The study was conducted in Mariculture Research and Development Center under Research Institute for Aquaculture No.3 (RIA. 3), located in Khanh Hoa province in Nha Trang city. The city is in the southern part of central Vietnam (Nha Trang), approximately 440 kilometers north of Ho Chi Minh City, 1280 kilometers south of Hanoi. It is located at 12.25 latitude and 109.19 longitudes and it is situated at elevation 10 meters above sea level. This area was selected due to the availability of hatcheries and other infrastructure for Mariculture activities.

\section{Broodstock collection and maintenance}

Adults and healthy broodstock of $H$. nobilis ( 80 individuals) with a mean weight between 700 to $1500 \mathrm{~g}$ were collected from the wild. The broodstock were collected during their reproductive season from March to July 2020. After collection, the brooders were stocked near to the sea in the flow-through system to adopt a new environment such as water depth. After one month, the healthy broodstocks were selected and then packed in the aerated plastic bag and the bags were placed in the box, then ice bugs were placed inside the box to maintain the temperature below $28^{\circ} \mathrm{C}$. Broodstock were then transferred to hatchery (Mariculture Research and Development Center (RIA 3)) by bus. The broodstock were stocked in 1000 I capacity tanks for acclimatization, stocking density as 40 specimens. Water in the tank was aerated, salinity was $32-34 \mathrm{ppt}$, and temperature $26-28^{\circ} \mathrm{C}$. During 
the acclimatization period, brooders were fed with microalgae $(20,000-40,000 \mathrm{cells} / \mathrm{ml})$, seaweed $\left(3 \mathrm{~g} / \mathrm{m}^{3}\right)$, and mud collected from mangrove-covered shore per day for one week before spawning induction.

\section{Inducing spawning and fertilization}

Two methods of inducing spawning were used, thermal stimulation and a combination of thermal and algal stimulation. The brooders were induced to spawn during the morning, around $9 \mathrm{am}$ to $11 \mathrm{am}$. Each spawning method was replicated four times from April to July. Twenty brooders were used in each spawning method.

\section{Thermal stimulation method}

Two tanks were prepared and filled with 800 l of filtered seawater at a salinity of $34 \mathrm{ppt}$. The water temperature in first tank was reduced to $23-24^{\circ} \mathrm{C}$ by adding ice and water temperature in the second tank was a standard temperature of $27-28^{\circ} \mathrm{C}$. Twenty brooders were cleaned and washed with filtered seawater to remove sediment and other organisms and then stocked to the tanks with water temperature reduced to $23-24^{\circ} \mathrm{C}$ and left for 2 hours. After 2 hours, the broodstock was transferred to the normal water temperature tank. The broodstock started to spawn after 30 minutes, males released sperm by raising the anterior end, then 30 minutes after the males had released sperm, and the females started releasing the eggs. Usually, males spawned first, which then induced them to release their eggs (Laxminarayana, 2005).

\section{The combination of thermal and algal stimulation methods}

Two tanks were prepared and filled with 800 I of filtered seawater at a salinity of $34 \mathrm{ppt}$. The water temperature in the first tank was reduced to $23-24^{\circ} \mathrm{C}$ by adding ice, while the water temperature in the second tank was a standard temperature of $27-28^{\circ} \mathrm{C}$. Twenty brooders were cleaned and washed with filtered seawater to remove sediment and associated organisms and then stocked to the tank with water temperature reduced to 23$24^{\circ} \mathrm{C}$ and left for 2 hours. After 2 hours, the broodstock was transferred to the standard water temperature tank, and then $2 \mathrm{~g}$ of dry algae Spirulina was added to the standard temperature tank. The broodstock started to spawn after 30 minutes, males started to spawn followed by females.

\section{Eggs collection}

After each successful spawning, the eggs were siphoned into the $80 \mu \mathrm{m}$ sieve and washed several times with filtered seawater to remove excess sperm and accumulated dirt during spawning. First, the number of fertilized eggs in each treatment was counted by placing the eggs in a bucket that contain 10 l (water was mixed gently to disperse the eggs in the water column). After that, five 1-ml subsamples were taken, and then the number of fertilized eggs was counted in each subsample using the Sedgewick-Rafter chamber under a light microscope. Eggs were incubated in a $1 \mathrm{~m} 3$ tank at a stocking density of $1 \mathrm{egg} / \mathrm{ml}$.

\section{Larval rearing with different diets}

Three days old $H$. nobilis larvae were stocked at three different diets of Nannochloropsis occulata, + Chaetoceros muellerii, + Isochrysis galbana, N. occulata + C. muellerii + I. Galbana, + Protein Selco (INVE Aquaculture, Belgium) and N. occulata + C. muellerii + I. Galbana, + Protein Selco and Frippak (INVE Aquaculture, Belgium) feed corresponding to treatment $\mathrm{T} 1, \mathrm{~T} 2$, and $\mathrm{T} 3$ respectively. Each treatment was replicated four times in a 10-liter plastic bucket at a salinity of $34 \mathrm{ppt}$. All experimental buckets were filled with filtered seawater and supplied with aeration. In the first 7 days of the experiment, $H$. nobilis larvae were fed exclusively $(100 \%)$ live microalgae ( $N$. occulata, C. muelleri, and I. galbana). From the 8th day, the larvae were fed on the combination of live microalgae and artificial feed to treat T2 and T3. For the microalgae, the feeding rate was increased gradually from 20,000 cells $/ \mathrm{ml}$ to 40,000 cells $/ \mathrm{ml}$ at a ratio of $1: 1: 1$ ) and 
for the artificial feed (Protein Selco and Frippak), the feeding rate was $1 \mathrm{~g} / \mathrm{m} 3 /$ day. The larvae were fed twice a day at 9 am and 4 pm for 17 days at a stocking density of 600 larvae/l.

Larval rearing at different stocking densities

Three-day-old $H$. nobilis larvae were stocked at three different stocking densities of 300,600 , and 1000 larvae/l. Each treatment was replicated four times in a 10-liter plastic bucket at a salinity of $34 \mathrm{ppt}$. All the experimental buckets were filled with filtered seawater and supplied with aeration. During the experiment, the larvae were fed with a combination of live microalgae ( $N$. occulata, $C$. muellerii, and $I$. galbana). The feeding rate was gradually increased from 20,000 cells $/ \mathrm{ml}$ to 40,000 cells $/ \mathrm{ml}$ at the ratio of $1: 1: 1 /$ day. The larvae were fed twice a day at 9 am and 4 pm for 17 days.

\section{Data collection and measurements}

Spawning response. The total number of spawned females was counted in each spawning method. The total number of fertilized eggs in each spawning method was counted by taking the average number of fertilized eggs of five-fold subsamples to the total volume of the water in the container (10l). Finally, the relative fecundity was counted by taking total number of fertilized eggs to divide by the average weight of the spawned female.

\section{Embryo and larval developmental stage}

Eggs and larvae samples were taken from water column after pausing aeration for 1 minute. Egg diameter and larvae size were measured by a graduated micrometer eyepiece and light microscope at 10X magnification. Larvae size was measured from prominent posterior protrusion ( $p$ ) to the anterior commissure (a) (Figure 1). For the first day, $10 \mathrm{ml}$ water samples (five subsamples) were taken from tank every 30 minutes; then from second day, samples were taken every 6 hours from the second day. $20 \mathrm{ml}$ of water samples (five subsamples) were taken from each bucket every day from third day (Günay et al., 2018).

\section{Growth and survival rate}

The total length of larvae (30 larvae) was measured every three days by taking $20 \mathrm{ml}$ (five subsamples) from the water Colum of each bucket. A graduated micrometer eyepiece measured the length, and light microscope at 10X magnification, measurement of the larvae size was done from the prominent posterior protrusion ( $p$ ) to the anterior commissure (a) (Figure 1). Then, $20 \mathrm{ml}$ (five subsamples) were taken from the water column of each rearing bucket and counted using a Sedge- wick-Rafter chamber under a microscope to calculate the survival rate. The Survival Rate (SR) is calculated by taking the final number of individual larvae divided by an initial number of individual larvae a hundred-fold.

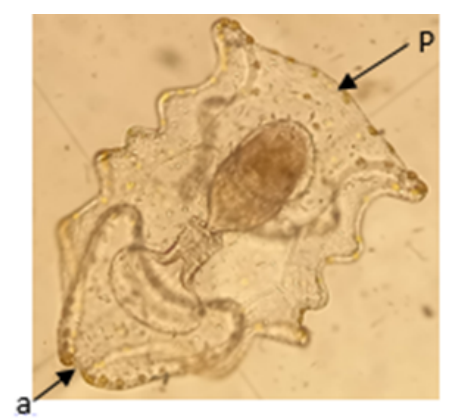

Figure 1 Early auricularia larvae of $H$. nobilis, posterior protrusion (p), anterior commissure (a)

Water quality parameters measurement 
Water temperature was measured daily morning and evening by using a mercury thermometer. In addition, $15 \mathrm{ml}$ of water from each rearing bucket was taken daily during the morning and evening to measure the concentration level of dissolved oxygen. At the same time, $30 \mathrm{ml}$ of water were taken from each rearing bucket after every two days to measure the concentration level of salinity, ammonia, nitrite, nitrate, and $\mathrm{pH}$. The concentration level of dissolved oxygen, salinity, ammonia, nitrite, nitrate, and $\mathrm{pH}$ in each rearing bucket was measured using water-quality reagent test kits.

\section{Data analysis}

The data were analyzed using SPSS. One-way ANOVA was used to assess the influence of the inducing spawning method on spawning response, relative fecundity and eggs fertilization, and the effect of different diets and stocking densities on the growth, development, and survival rate larvae. In addition, Duncan's multiple range test was used to detect significant differences among the treatments at the 0.05 significance level.

\section{Spawning response.}

\section{Results}

During spawning, males of $H$. nobilis spawned continuously before females by releasing a thin and steady stream of sperm from their gonopore, females began spawning approximately 30 minutes later. The females lifted the anterior end of the body from the tank, moving and twisting upward until a short and powerful jet of eggs was released from their gonopore. Females spawned with 4-10 distinct squirts with 3-15 min intervals between each squirt. The powerful ejection facilitates the eggs dispensation much more widely with respect to the streams of sperm for fertilization. The average number of females spawned of $H$. nobilis was higher in a combination of thermal and algal stimulation methods, however, the number of fertilized eggs and relative fecundity was higher in thermal stimulation method compared to combination of thermal and algal stimulation method (Table 1).

Table 1 The number of females spawned, relative fecundity (number of fertilized eggs $/ \mathrm{kg}$ ) and total number of fertilized eggs produced by each inducing spawning method (Mean \pm SD).

\begin{tabular}{llll}
\hline \multirow{4}{*}{ Parameters } & \multicolumn{3}{l}{ inducing spawning method } \\
& $\begin{array}{l}\text { Thermal } \\
\text { stimulation } \\
\text { method }\end{array}$ & $\begin{array}{l}\text { Combination of } \\
\text { thermal and algal } \\
\text { stimulation method }\end{array}$ & P-value \\
\hline Number of female spawned & $3 \pm 0.81$ & $6 \pm 3.09$ & 0.14 \\
Weight of female spawned $(\mathrm{kg})$ & $1.1 \pm 0.15$ & $1.0 \pm 0.14$ & 0.49 \\
Number of fertilized eggs & $1.3 \pm 0.32$ & $0.8 \pm 0.38$ & 0.07 \\
Number of fertilized eggs $/ \mathrm{kg}$ & $1.2 \pm 0.21$ & $0.8 \pm 0.39$ & 0.10 \\
\hline
\end{tabular}

\section{Embryonic and larval development}

The development of $H$. nobilis started with the elevation of the fertilization envelope; within 5 min after fertilization, the membrane of the fertilized eggs swelled and increased to a mean diameter of $170.2 \pm 7.82 \mu \mathrm{m}$ (Figure 2). The first cleavage was equal, radial, and holoblastic and divided the cell into two equals hemispheric blastomeres with a mean diameter of $173.3 \pm 4.80$ (Figure $2 \mathbf{C}$ ). The second, third, and fourth cleavage occurs along the animal-vegetal axis, resulting in the more spherical blastomeres; the cleavage was observed at 100,160 , and 180 min with the diameter of $178.3 \pm 4.80,177.3 \pm 6.92$, $181.3 \pm 6.23(\mu \mathrm{m})$ respectively (Table $\mathbf{2}$ ). The morula stage (Figure $2 \mathbf{~ G}$ ) appeared 4 hours after fertilization and the blastula stage was reached 5 hours after fertilization, with a typical central blastocoele surrounded by a single layer of cells (Figure 2). The embryo started moving, and at 16 hours, the blastopore start forming and the first gastrula was observed (mean length $207.8 \pm 8.17 \mu \mathrm{m}$ ) (Table 2). The embryos hatched as late gastrulae $32 \mathrm{~h}$ after fertilization mean length $275.5 \pm 18.12 \mu \mathrm{m}$. The body surface of 
gastrulae was covered with cilia purposively for swimming. Early auricularia larvae begin to appear 3days after fertilization (mean length $523.9 \pm 73.32 \mu \mathrm{m}$ ). The larvae were transparent, slipper-shaped with ciliary bands for locomotion, single pre-oral anterior lobe and posterior anal lobe, completed digestive system (mouth, esophagus, and stomach), slow-moving but continuous activity, pelagic and first actively feeding stage on live microalgae.

Mid auricularia larvae appeared from 7-12 days after fertilization (mean length 928.3 $\pm 55.30 \mu \mathrm{m}$ ), lateral projections in the mid auricularia became more prominent, and the digestive tract, cloaca as well as anus were visible. At 12-15 days after fertilization, the larvae become late auricularia stage; at this stage, hyaline spheres appeared at the tips of the projection (the hyaline sphere is a lipid reserve used during metamorphosis and settlement). The larvae reach its maximum size of $988.9 \pm 24.58 \mu \mathrm{m}$ (mean \pm SD) and it has left and right somatocoels, as well as an axohydrocoel. At 16 days after fertilization, few auricularia larvae started to transform into the doliolaria stage (mean length $565.2 \pm$ $84.19 \mu \mathrm{m}$ ); during this stage, the larvae shrink down to nearly $60 \%$ of the late auricularia. The buccal cavity disappears and the hyaline spheres are compressed closer together (Figure 2.0). The doliolaria stage was completed after 2-3 days (16-18 days after fertilization); they are fast-moving and non-feeding. They have a barrel-shaped, darkbrown body with 5 ciliated bands around the body and 5 hyaline spheres on each side, primary tentacles, ciliary bands, and somatocoel became visible. The larvae started swimming close to the substrate then, plastic sheets (as a substrate) were placed in the larval tanks as soon as the first doliolaria larva was observed, as they need a favorable substratum to settle on and metamorphose into pentactula larvae.

Table 2 Embryonic and larval development of $H$. nobilis with size (mean $\pm \mathrm{SD} ; \mathrm{n}=30$ ) at $28-29.5^{\circ} \mathrm{C}$.

\begin{tabular}{lll}
\hline \multicolumn{3}{c}{ Embryo and larvae development } \\
\cline { 2 - 3 } \multicolumn{1}{c}{ Stage } & $\begin{array}{l}\text { Time }(\min , h, \\
\text { d) }\end{array}$ & Size \\
\hline Unfertilized egg & $0-\mathrm{min}$ & $153.7 \pm 18.10$ \\
Fertilized egg & $0-5 \mathrm{~min}$ & $170.2 \pm 7.82$ \\
2-cell division & $90-\mathrm{min}$ & $173.3 \pm 4.80$ \\
4-cell division & $100-\mathrm{min}$ & $178.3 \pm 4.80$ \\
8-cell division & $160-\mathrm{min}$ & $181.3 \pm 6.23$ \\
16-cell division & $180-\mathrm{min}$ & $181.3 \pm 6.23$ \\
Morula & $4 \mathrm{~h}$ & $180.2 \pm 9.70$ \\
Blastula & $5 \mathrm{~h}$ & $180.2 \pm 8.86$ \\
Rotary blastula & $9 \mathrm{~h}$ & $177.7 \pm 7.16$ \\
Early gastrula & $16 \mathrm{~h}$ & $207.8 \pm 8.17$ \\
Late gastrula & $32 \mathrm{~h}$ & $275.5 \pm 18.12$ \\
Early auricularia & $3-6 \mathrm{~d}$ & $523.9 \pm 73.32$ \\
Mid auricularia & $7-12 \mathrm{~d}$ & $928.3 \pm 55.30$ \\
Late auricularia & $12-15 \mathrm{~d}$ & $988.9 \pm 24.58$ \\
Doliolaria & $16-18 \mathrm{~d}$ & $565.2 \pm 84.19$ \\
\hline
\end{tabular}

h: hours; min: minutes; d: days. 


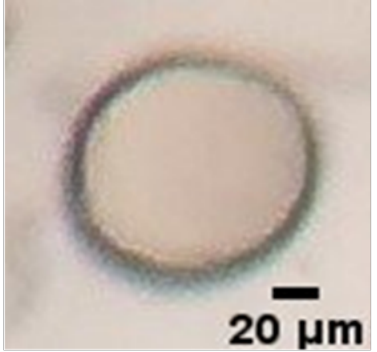

A

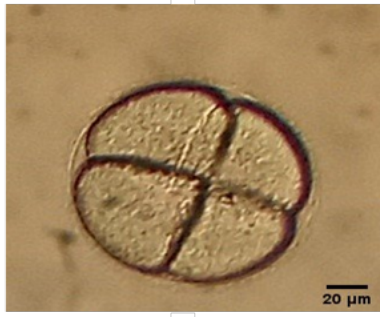

D

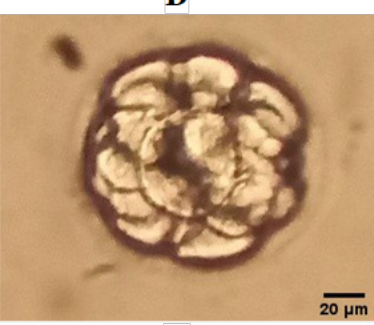

G

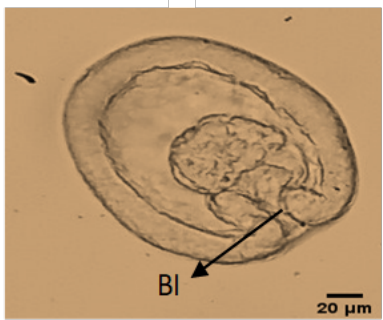

$\mathbf{J}$

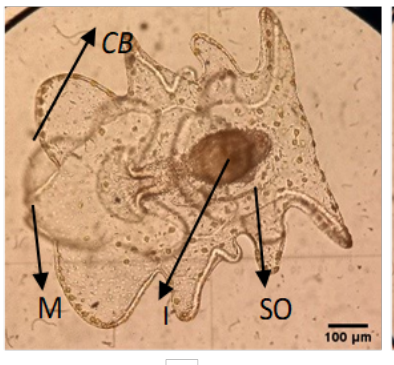

M

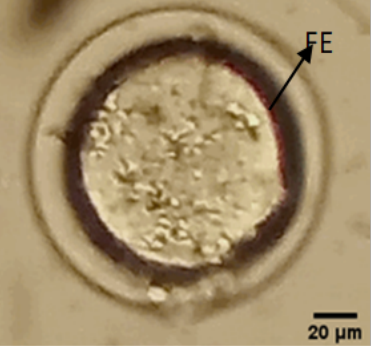

B

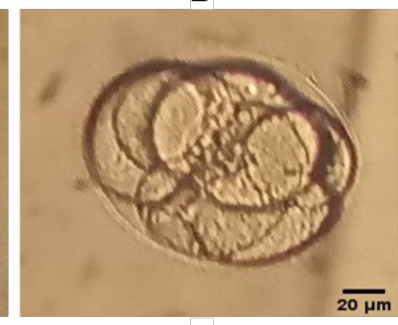

E

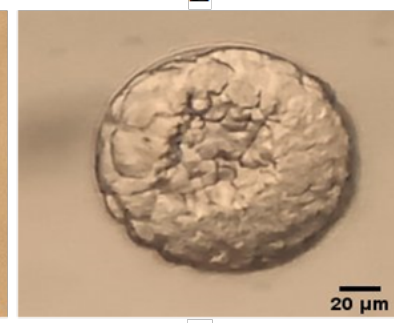

H

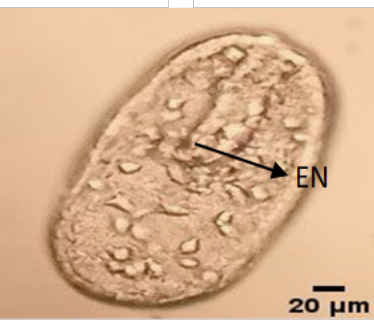

$\mathbf{K}$

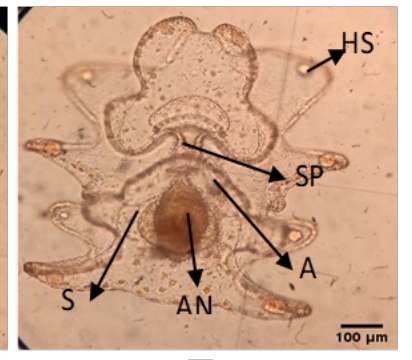

$\mathbf{N}$

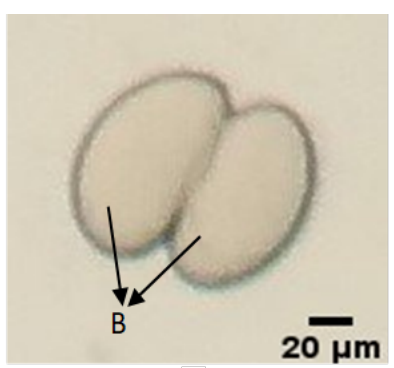

C

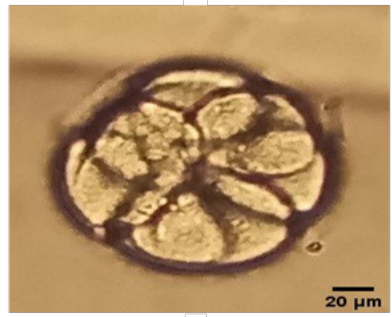

F

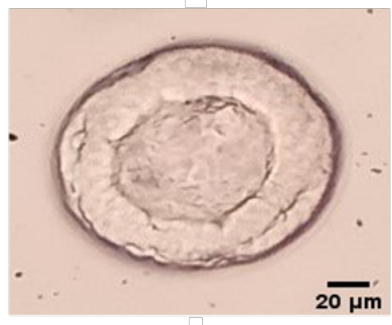

I

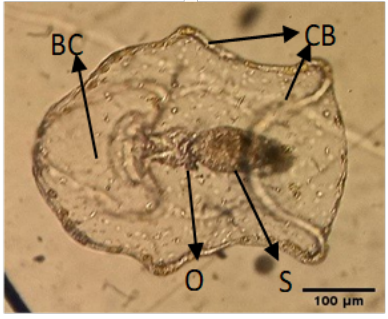

L

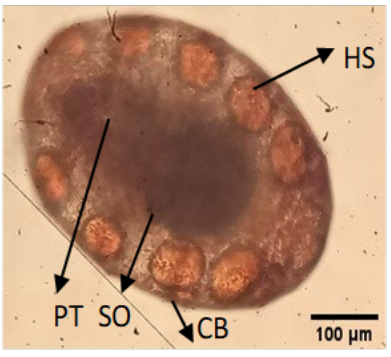

O

Figure 2 Embryonic and larval development of H. nobilis

A) Unfertilized egg. B) Fertilized egg with fertilization envelope (FE). C) First cleavage with blastomeres (B). D) Second cleavage. E) Third cleavage. F) Fourth cleavage. G) Morula. $\mathrm{H}$ ) Blastula I) Rotary blastula. J) Early gastrula with blastopore (BI). K) Late gastrula with enterocoeles (EN). L) Early auricularia with well-developed buccal cavity (BC), oesophagus $(\mathrm{O})$, ciliary bands $(\mathrm{CB})$ and stomach $(\mathrm{S})$. M) Mid auricularia with ciliary bands (CB), intestine (I), somatocoel (SO) and mouth (M). N) Late auricularia with hyaline spheres (HS), stomach (S), sphincter (SP), axohydrocoel (A) and anus (AN). O) Doliolaria with hyaline spheres (HS), ciliary band (CB), somatocoel (SO) and primary tentacles (PT). 
Water quality parameters during the feeding experiment

The water quality ((salinity, temperature, dissolved oxygen and $\mathrm{pH}$ was normal for the growth and survival rate of sea cucumber larvae (Agudo, 2006). However, in the treatments (T2 and T3), the quantity of $\mathrm{NO}_{2}(\mathrm{mg} / \mathrm{l})$ and $\mathrm{NO}_{3}(\mathrm{mg} / \mathrm{l})$ was above the average of optimal conditions (Table $\mathbf{3}$ ).

Table 3 Water quality parameters during the feeding experiment ( $N$. oculata $+C$. muellerii + I. galbana (T1), N. oculata + C. muellerii + I. galbana + Protein selco (T2) and $N$. occulata + C. muellerii + I. galbana + Protein selco and Frippak (T3) (mean \pm SD).

\begin{tabular}{|c|c|c|c|c|c|c|c|}
\hline \multirow[b]{2}{*}{ Treatments } & \multicolumn{7}{|c|}{ Water quality parameters } \\
\hline & $\begin{array}{c}\text { Temperature } \\
\left({ }^{\circ} \mathrm{C}\right)\end{array}$ & $\begin{array}{l}\text { Salinity } \\
(\% o)\end{array}$ & $p H$ & $D O(m g / l)$ & $\mathrm{NH3}(\mathrm{mg} / \mathrm{l})$ & $\mathrm{NO} 2-(\mathrm{mg} / \mathrm{I})$ & NO3- $(\mathrm{mg} / \mathrm{l})$ \\
\hline $\mathrm{T} 1$ & $28.9 \pm 0.63^{a}$ & $33.0 \pm 0.82^{a}$ & $8.2 \pm 0.06^{\mathrm{a}}$ & $5.8 \pm 0.29^{a}$ & $0.2 \pm 0.08^{a}$ & $0.2 \pm 0.09^{a}$ & $6.3 \pm 2.50^{a}$ \\
\hline T2 & $28.5 \pm 0.58^{a}$ & $33.3 \pm 0.96^{a}$ & $8.1 \pm 0.09^{a}$ & $5.5 \pm 0.41^{a}$ & $0.5 \pm 0.05^{\mathrm{b} *}$ & $0.6 \pm 0.06^{\mathrm{b} *}$ & $12.5 \pm 2.89^{b *}$ \\
\hline T3 & $28.6 \pm 0.75^{a}$ & $33.0 \pm .0 .79^{a}$ & $8.2 \pm 0.07^{a}$ & $5.5 \pm 0.37^{a}$ & $0.6 \pm 0.15^{\mathrm{b} *}$ & $0.6 \pm 0.09^{\mathrm{b} *}$ & $17.5 \pm 2.89^{c *}$ \\
\hline
\end{tabular}

\section{Growth performance}

The total length $(\mu \mathrm{m})$ of larvae fed different diets was significantly different $(P<0.05)$, the growth was significantly increased from the first day to 15 th day and sharply decreased on day 18 in all treatments (Table 4).

Table 4 Total length $(\mu \mathrm{m})$ of $H$. nobilis larvae fed different diets $(N$. occulata + C. muellerii + I. galbana (T1), N. occulata + C. muellerii + I. galbana + Protein selco (T2) and $N$. oculata + C. muellerii $+I$. galbana + Protein selco and Frippak (T3) (mean $\pm \mathrm{SD} ; \mathrm{n}=30)$.

\begin{tabular}{lllll}
\hline & & \multicolumn{3}{c}{ Treatments } \\
$\begin{array}{l}\text { Days after } \\
\text { fertilization }\end{array}$ & $\begin{array}{l}\text { Larval development } \\
\text { stage }\end{array}$ & $T 1$ & $T 2$ & $T 3$ \\
\hline 03 & Early auricularia & $446.3 \pm 18.10^{\mathrm{a}}$ & $446.3 \pm 18.10^{\mathrm{a}}$ & $446.3 \pm 18.10^{\mathrm{a}}$ \\
06 & Early auricularia & $652.0 \pm 12.15^{\mathrm{a}}$ & $651.0 \pm 11.25^{\mathrm{b}}$ & $650.7 \pm 7.85^{\mathrm{ab}}$ \\
09 & Mid auricularia & $752.0 \pm 9.97^{\mathrm{a}}$ & $750.7 \pm 6.12^{\mathrm{a}}$ & $747.0 \pm 7.50^{\mathrm{a}}$ \\
12 & Mid auricularia & $843.7 \pm 18.66^{\mathrm{b}}$ & $840.0 \pm 10.83^{\mathrm{b}}$ & $829.7 \pm 15.86^{\mathrm{a}}$ \\
15 & Late auricularia & $951.0 \pm 8.85^{\mathrm{c}}$ & $938.3 \pm 7.92^{\mathrm{b}}$ & $932.3 \pm 10.40^{\mathrm{a}}$ \\
18 & Doliolaria & $538.7 \pm 8.99^{\mathrm{a}}$ & $538.0 \pm 7.61^{\mathrm{a}}$ & $539.7 \pm 9.28^{\mathrm{a}}$ \\
\hline Means in the same raw having different letters are significantly different $(P \leq 0.05)$
\end{tabular}

\section{Survival rate}

The survival rate and percentage of larvae reached dolioralia stage were statistically higher in T1 (27.5\% and 5.3\% respectively) followed by T2 (12.8\% and 3.7\% respectively) and the last was T3 $(9.2 \%$ and $2.5 \%$ respectively) on day $18(P<0.05)$. The low survival rate in treatment T2 and T3 was attributed to poor water quality due to the high accumulation of nitrogenous waste caused by artificial feed (Figure $\mathbf{3}$ and $\mathbf{4}$ ). 


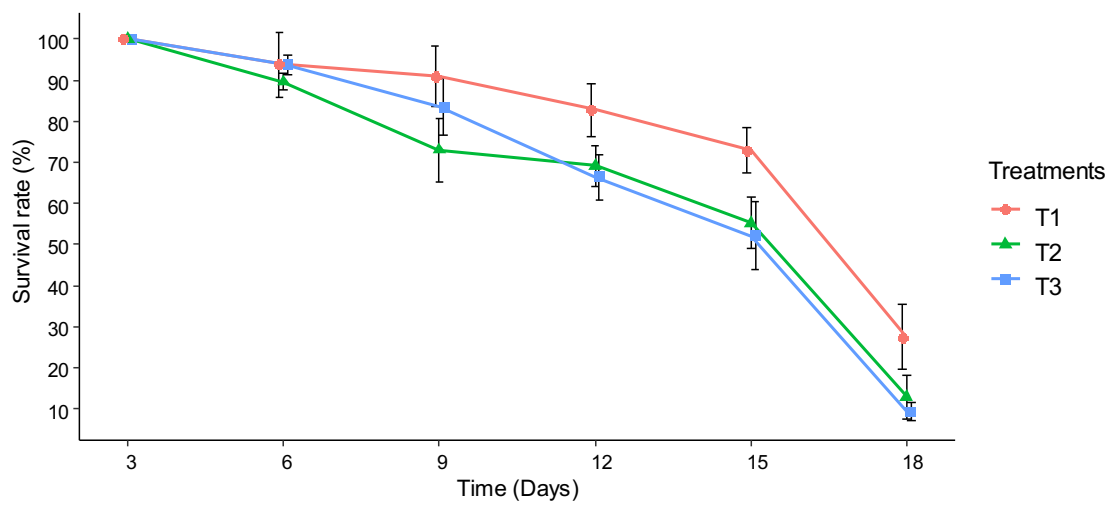

Figure 3 Survival rate (\%) of $\mathrm{H}$. nobilis larvae fed different diets ( $\mathrm{N}$. oculata $+\mathrm{C}$. muellerii $+\mathrm{I}$. galbana (T1), N. occulata + C. muellerii + I. galbana + Protein Selco (T2) and N. oculata + C. muellerii + I. galbana + Protein Selco and Frippak (T3) (mean \pm SD).

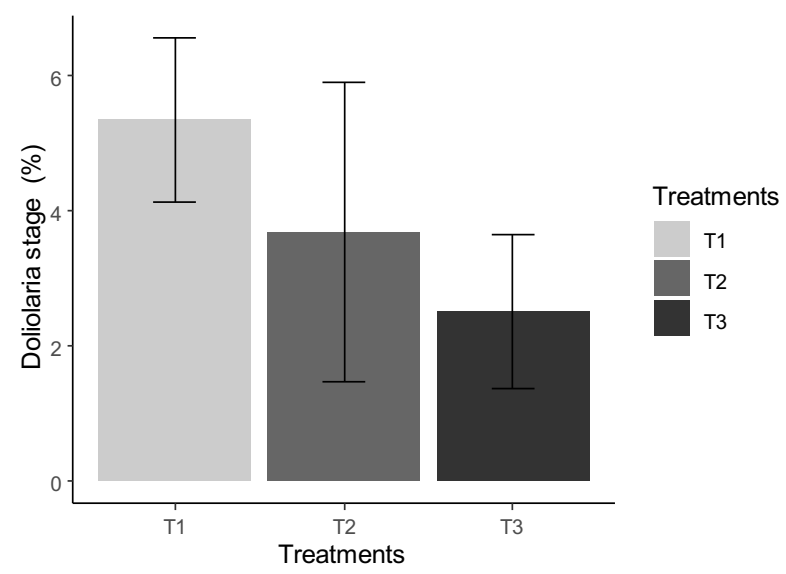

Figure 4 Percentage of larvae reached dolioralia stage on day 18 at different diets $(N$. oculata $+C$. muellerii + I. galbana (T1), N. occulata + C. muellerii + I. galbana + Protein Selco (T2) and $N$. oculata + C. muellerii + I. galbana + Protein Selco + Frippak (T3) (mean \pm SD).

Water quality parameters during the stocking density experiment

Water quality (salinity, temperature, dissolved oxygen, and $\mathrm{pH}$ ) was typical for sea cucumber larvae's growth and survival rate. However, in stocking density of 1000 larvae/l, the concentration of $\mathrm{NO}_{2}(\mathrm{mg} / \mathrm{l})$ and $\mathrm{NO}_{3}(\mathrm{mg} / \mathrm{l})$ was above average of optimal conditions. (Table 5).

Table 5 Water quality parameters during the stocking density experiment (mean \pm SD)

\begin{tabular}{|c|c|c|c|c|c|c|}
\hline \multirow[b]{2}{*}{ Treatments } & \multicolumn{6}{|c|}{ Water quality parameters } \\
\hline & $\begin{array}{c}\text { Temperature } \\
\left({ }^{\circ} \mathrm{C}\right)\end{array}$ & $\begin{array}{l}\text { Salinity } \\
(\% o)\end{array}$ & $p H$ & $D O(m g / l) \quad N H 3(m g / l)$ & $\mathrm{NO} 2-(\mathrm{mg} / \mathrm{l})$ & NO3- $(\mathrm{mg} / \mathrm{l})$ \\
\hline 300 larvae/l & $28.6 \pm 0.75^{\mathrm{a}}$ & $32.6 \pm 0.95 a$ & $8.1 \pm 0.09^{a}$ & $5.5 \pm 0.41 a 0.2 \pm 0.09^{a}$ & $0.2 \pm 0.09^{a}$ & $6.2 \pm 2.5^{\mathrm{a}}$ \\
\hline 600larvae/l & $28.2 \pm 0.50^{\mathrm{a}}$ & $33.3 \pm 0.95 a$ & $8.2 \pm 0.57^{a}$ & $5.6 \pm 0.47 \mathrm{a} \quad 0.5 \pm 0.05^{\mathrm{b} *}$ & $0.2 \pm 0.08^{\mathrm{a}}$ & $6.2 \pm 2.5^{\mathrm{a}}$ \\
\hline $\begin{array}{l}1000 \\
\text { larvae/l }\end{array}$ & $28.6 \pm 0.75^{a}$ & $33.3 \pm .0 .90 \mathrm{a}$ & $8.1 \pm 0.10^{\mathrm{a}}$ & $5.5 \pm 0.39 a \quad 0.6 \pm 0.13^{b} *$ & $0.5 \pm 1.9^{\mathrm{b} *}$ & $10 \pm 4.08^{a}$ \\
\hline
\end{tabular}

Means in the same column having different letters are significantly different $(P \leq 0.05)$

Note: Value with stars* shows the value above the average of the optimal condition

Growth performance

The total length $(\mu \mathrm{m})$ of larvae at different stocking densities differ during the experimental period $(P<0.05)$. The length was significantly increased from day 3rd to 15th $(P<0.05)$ and sharply decreased during the metamorphosis period (18 days) $(P<$ 0.05) (Table 6). 
Table 6 Total length $(\mu \mathrm{m})$ of $H$. nobilis larvae at different stocking densities (mean $\pm \mathrm{SD} ; \mathrm{n}=30$ )

\begin{tabular}{|c|c|c|c|c|}
\hline \multirow[b]{2}{*}{$\begin{array}{l}\text { Days after } \\
\text { fertilization }\end{array}$} & \multicolumn{4}{|c|}{ Treatments } \\
\hline & $\begin{array}{l}\text { Larval development } \\
\text { stage }\end{array}$ & 300 larvae/L & 600 larvae/L & 1000 larvae/L \\
\hline 03 & Early auricularia & $446.3 \pm 18.10^{a}$ & $446.3 \pm 18.10^{\mathrm{a}}$ & $446.3 \pm 18.10^{\mathrm{a}}$ \\
\hline 06 & Early auricularia & $648.7 \pm 8.19^{a}$ & $656.7 \pm 7.58^{\mathrm{b}}$ & $653.3 \pm 11.84^{\mathrm{ab}}$ \\
\hline 09 & Mid auricularia & $799.0 \pm 22.80^{a}$ & $796.0 \pm 13.03^{a}$ & $798.7 \pm 16.55^{a}$ \\
\hline 12 & Mid auricularia & $905.7 \pm 18.88^{a}$ & $911.3 \pm 19.25^{\mathrm{a}}$ & $903.0 \pm 17.65^{a}$ \\
\hline 15 & Late auricularia & $947.0 \pm 13.43^{a}$ & $961.3 \pm 8.19^{b}$ & $959.0 \pm 10.33^{b}$ \\
\hline 18 & Doliolaria & $552.7 \pm 17.01^{a}$ & $551.0 \pm 13.98^{\mathrm{a}}$ & $552.7 \pm 16.60^{a}$ \\
\hline
\end{tabular}

\section{Survival rate}

The higher survival rate was in the stocking density of 600 larvae/l, followed by 300 larvae/l, and the lowest survival rate was observed in the stocking density of 1000 larvae/l (Figure 5). On day 18, the survival rate in all treatments sharply decreased up to $41.5 \%$, $37.9 \%$ and $21.7 \%$ in stocking density of 600,300 , and 1000 larvae/l respectively (Figure 5 and 6$)$.

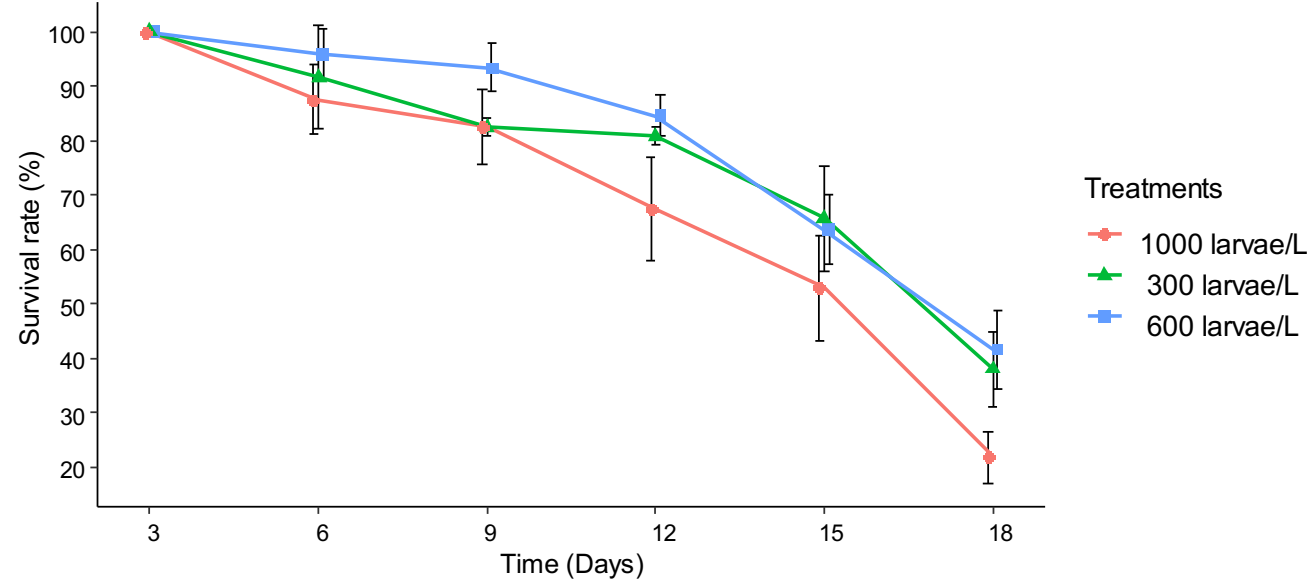

Figure 5 Survival rate (\%) of $H$. nobilis larvae at different stocking densities

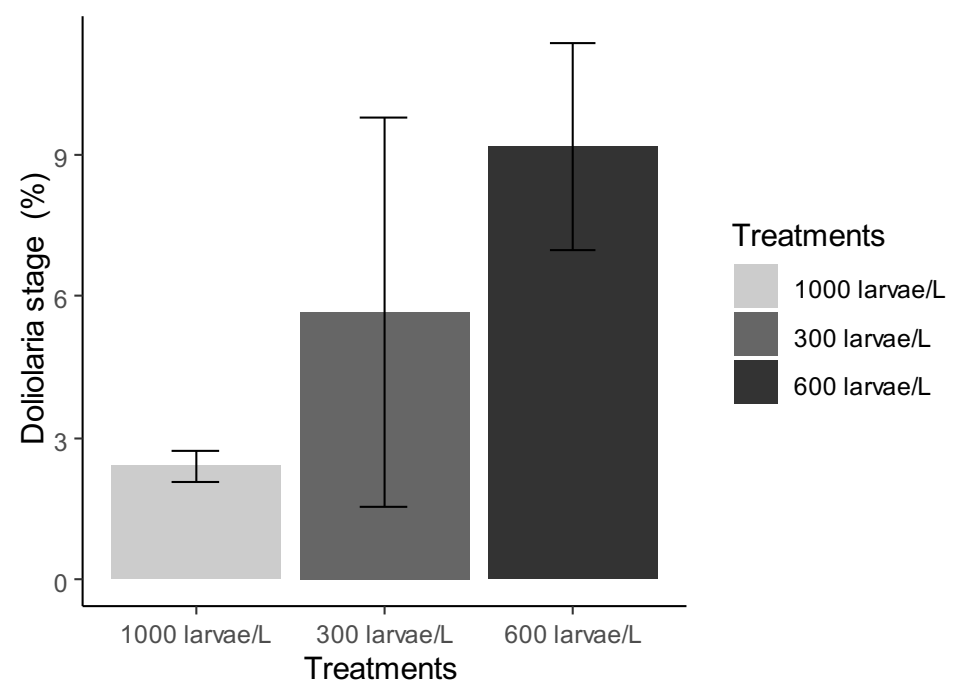

Figure 6 Percentage of larvae reached doliolaria stage at different stocking densities on day 18 


\section{Discussion}

Spawning response

In this study, thermal stimulation method gave a better result by producing $1,300,000$ fertilized eggs compared with a combination of thermal and algal stimulation (dry Spirulina), which produced only 800,000 fertilized eggs. The effectiveness of thermal stimulation method on inducing spawning to the sea cucumber species such as Actinopyga mauritiana, Australostichopus mollis, $H$. arguinensis, Holothuria atra, Holothuria fuscogilva, S. horrens, and H. scabra have been reported by (Battaglene, 1999; Domínguez-Godino and González-Wangüemert, 2019; Laxminarayana, 2005). The thermal stimulation method effectively induced spawning in sea cucumber, probably due to the fact that, temperature is the main factor in inducing gonadal maturation in the wild (Muthiga et al., 2009). Therefore, in artificial breeding, a slow and progressive increase in temperature stimulates spawning (Arnold et al., 2018). The combination of thermal and algal stimulation methods produced little fertilized eggs compared to the thermal stimulation method, this may be due to the characteristics of its natural habitat. $H$. nobilis live in a shallow and clear environment; perhaps the addition of dry algae Spirulina clouded the water resulting in poor spawning. Razek et al. (2012) reported a similar situation in $H$. arenicola; no spawning response was noted by using drying and addition mixture of diatoms and microalgae. The failure of $H$. arenicola may be due to the characteristics of its natural habitat, which they collected from clear environment.

\section{Embryonic and larval development}

The embryonic and larval development stages of $H$. nobilis consisted of the early, midlate auricularia, and doliolaria stage, similar to many sea cucumber species. The time registered for $H$. nobilis larvae to reach doliolaria stage was similar with $H$. mammata (1718 days) (Domínguez-Godino and González-Wangüemert, 2018) and $H$. scabra (17 days) (Ivy et al., 2006). The duration of the different larval stages and the overall larval life cycle differ between and within species (Agudo, 2006). Stages of larval development of the $H$. nobilis differ from $\mathrm{H}$. leucospilota (Dabbagh et al., 2011), Pseudocolochirus violaceus, and Colochirus quadrangularis (Ajith Kumara et al., 2013) and H. tubulosa (Arnold et al., 2018).The similarity and differences of $\mathrm{H}$. nobilis with other species in some parts of their life cycle could be attributed to environmental conditions such as photoperiod, water temperature, and food (Nathlie et al., 2017). As this is often the primary report of induced spawning and larval rearing of $H$. nobilis, there are no published reports to compare spawning efficient and larval development stages within the species.

\section{Growth performance of $H$. nobilis larvae fed different diets.}

Three diets were tested ( $N$. oculata $+C$. muellerii $+I$. galbana $(T 1), N$. oculata $+C$. muellerii + I. galbana + Protein Selco (T2), and N. oculata + C. muellerii + I. galbana + Protein Selco + Frippak (T3). The artificial feeds were used as a nutrient supplement especially lipid. Lipid content required by the larvae to enhance the development of the lipid riched structure called hyaline spheres, the hyaline spheres contain nutrients used by the larvae to complete the metamorphosis into the doliolaria stage(Abidin et al., 2019). The results from this study show that the total length of $H$. nobilis larvae (Table 4) between the treatments was highly significant $(P<0.05)$, T1 was the best in growth performance followed by T2 and the least was T3. The poor growth rate in T2 and T3 was probably attributed to overfeeding; overfeeding decrease food ingestion rate. (Arnold et al. (2018) reported that too much feed leads to larval degeneration and loss, highlighting overfeeding as a bottleneck for juvenile production. In the natural environment, deposit feeders consume large amounts of low nutritive value sediment to obtain a net energy input (I R Hudson et al., 2005). However, when food quality becomes better, internal appetite regulation would work actively to decrease food ingestion. As observed in this study, the growth rate of $\mathrm{H}$. nobilis larvae grew poor in the mixture of microalgae with the addition of high protein artificial feed (Frippack and Protein Selco), this probably leads to the lower ingestion of excess protein present in artificial feed. 
The same phenomenon was also found in other echinoderms, Fernandez and Boudouresque (1998) reported that sea urchin (Strongylocentrotus franciscanus) fed with diets of different protein levels resulted in different ingestion rates. Maria del Mar Otero Villanueva (2005) also found in Psammechinus miliaris that rock bottom ingestion rate was associated with a high energy and protein diet. Therefore, a high amount of protein may not have been utilized by larvae, and probably accumulated as waste in the culture environment. The dead microalgae and artificial feed particles (Frippack) are non-buoyant and settle more rapidly than live microalgae, potentially resulting in the accumulation of nitrogenous waste which pollutes the water (Morgan, 2001). Not only that but also protein selco cover the water surface which results in poor dissolved oxygen into the rearing system. Therefore, the optimization of feeding and culture system example use of a flowthrough system may reduce particle settlement and excessive food wastage which will enhance the effectiveness of artificial feeds during hatchery culture. The use of artificial feed may be useful during the post-settlement larvae culture of sea cucumbers. The characteristic of the Frippack and other artificial feed suits the feeding behavior of postsettlement sea cucumber larvae because, at settlement (pentactula and juvenile stage), sea cucumber become grazers and forage detrital organic matter and are capable of digesting carbon sources from microbial and fungal degradation (Nguyen Dinh Quang, 2017).

In general, the growth performance of $H$. nobilis larvae fed different diets was higher compared to other reported sea cucumber species. For example, the maximum size of $H$. nobilis larvae at late auricularia stage was $(951.0 \pm 8.85 \mu \mathrm{m})$, which is higher than Holothuria mammata that attained late auricularia stage with the mean length of 433 $\mu \mathrm{m}$ (Domínguez-Godino and González-Wangüemert, 2018), Holothuria spinifera mean length $809 \mu \mathrm{m}$ (Asha and Muthiah, 2002) and Holothuria polii mean length of $705 \mu \mathrm{m}$ (Arnold et al., 2019). In all treatments, the larvae increased in size from day 3 to day 15 and sharply decreased on day 18 ; the decreased in size was because of its morphological changes, the late auricularia metamorphosed into the non-feeding doliolaria, at this stage, the larvae became smaller than in the previous stages, with a mean length of (538.7 \pm $8.99 \mu \mathrm{m})$. The decreased in size in the dolioralia stage has been reported to many sea cucumber species, Arnold et al. (2019) reported for $\mathrm{H}$. polii whereby at the doliolaria stage, the larvae became smaller than in the previous stages, with a mean length of $375.07 \pm$ $28.37 \mu \mathrm{m}$. Doliolaria larvae of $H$. tubulosa, $H$. mammata and $H$. spinifera became smaller than in the late auricularia stages, with a mean length of $423.6 \pm 6.6,506.21 \pm 27.13$ and 468 $\pm 57 \mu \mathrm{m}$ respectively (Asha and Muthiah, 2005: Domínguez-Godino and onzálezWangüemert, 2018: Arnold et al., 2018). The change of its anatomy and physiology results in the larvae not able to obtain external sources of food, this could be the reason why the doliolaria larvae become smaller than the late auricularia

\section{Survival rate of $\mathrm{H}$. nobilis larvae fed different diets}

The survival rate of larvae fed the combination of microalgae and artificial feed was lower in the present study. However, the results from this study were higher compared to commonly reported rates of survival in many sandfish hatcheries of around $1 \%$ (Purcell et al., 2012). Abidin et al. (2019) reported a low survival rate (less than 1.5\%) of sandfish larvae fed a different mixture of microalgae (Nannochloropsis sp. + C. calcitrans). On another side, this study's survival rate was lower than Holothuria spinifera Theel, which attained the survival rate of (100\%) when fed the combined microalgae (Asha and Muthiah, 2006 ). The survival rate of larvae was sharply decreased to $27.5 \%$ in $\mathrm{T} 1,12.8 \%$ in $\mathrm{T} 2$, and $9.2 \%$ in T3 on day 18 . The reduction in the survival rate of larvae in the doliolaria stage have also reported in $H$. scabra (Ivy et al., 2006). B. marmorata, $H$. atra (Laxminarayana, 2005), H. spinifera (Asha and Muthiah, 2002), H. scabra (Mazlan and Hashim, 2015) and P. violaceus ((Ajith Kumara et al., 2013) with survival rates of $20 \%-30 \%, 13.2 \%, 6.4 \%$, $5 \%, 4.2 \%$, and $0.7 \%$ respectively, a sharp decrease in survival was caused by physiological changes of larvae toward the dolioralia stage.

The effectiveness of using mixed microalgae on growth rate has been reported in $\mathrm{H}$. scabra, S. japonicus, H. atra, and H. spinier (Asha and Muthiah, 2002; Ramofafia et al., 
2003). Battaglene (1999) reported better growth performance of the sandfish larvae when fed with the mixture of Rhodomonas salina and C. muellerii. Asha and Muthiah (2006) reported the combination of $C$. calcitrans and $I$. galbana to be the best diets in the growth performance of $H$. spinifera larvae. However, Sun and Li (2012) stated that larvae fed with single algae of $I$. galbana showed the maximum growth rate compared to those fed with the mixture of C. calcitrans, N. salina, and T. chuii. Meanwhile, the result from this study shows the combination of $N$. occulata $+C$. muellerii $+I$. galbana to be the best feed for better development, growth, and survival rate of $H$. nobilis larvae.

\section{Growth performance of larvae stocked at different stocking densities}

The highest length gain in the stocking density of 600 larvae/l could be attributed to low competition for feed compared to the stocking density of 1000 larva/l. A feed is an external factor that had the most prominent effect on the growth of organisms. The limited available feed has a high stocking density because the sea cucumber has a lower chance of finding enough feed, resulting in slow growth and high size variability (Sun and Li, 2012). Serang, Tua et al. (2016) reported high growth of Holothuria scabra larvae in low stocking density; this indicates that low stocking density reduces feed competition compared to high stocking density lower the availability of feed to the larvae.

The stocking density of 300 larvae/l had a low total length compared to the stocking density of 600 larvae/I and 100 larvae/l; this could be because of higher availability of feed to the larvae because of low density as in the present study, the same amount of live microalgae (20000-40000) cells/ml was given to the all tested stocking densities. Morgan (2001) observed that at a low concentration of 10000 and $20000 \mathrm{cells} / \mathrm{ml}$ of the live microalgae, larvae' growth and development increased substantially. However, at higher availability of feed (higher concentrations of microalgae), larval growth was low. Arnold et al. (2018) indicated that high algal concentration leads to larval degeneration and loss.

The total length significantly increased from day 3 to 15 in all treatments. However, on day 18 , the growth performance sharply decreased due to the metamorphosis process of late auricularia larvae to the dolioralia stage. The decrease in length at this stage has also been reported by many researchers such as Arnold et al. (2019) reported for H. polii whereby at the doliolaria stage, the larvae became smaller than in the previous stages, with a mean length of $375.07 \pm 28.37 \mu \mathrm{m}$. Doliolaria larvae of $H$. tubulosa became smaller than in the late auricularia stages, with a mean length of $423.6 \pm 6.6 \mu \mathrm{m}$ (Arnold et al., 2018), Holothuria mammata $(506.21 \pm 27.13 \mu \mathrm{m})$ (Domínguez-Godino and GonzálezWangüemert, 2018) and Holothuria spinifera $468 \pm 57 \mu m$ ( Asha and Muthiah, 2005).

\section{Survival rate of larvae stocked at different stocking densities}

The decreased survival rate on day 18 was due to the change of morphological features in the late auricularia stage toward the dolioralia stage (metamorphosis process). The lowest survival rate of larvae was observed at a stocking density of 1000 larvae/ml; this could be attributed to high competition of space and food. The same situation was observed in $H$. scabra whereby the low survival rate of the larvae obtained in high stocking density (>2larvae/ml) (Serang et al., 2016). The low survival rate was due to the feeding and space competitions ((Asha and Diwakar, 2013).

The percentage of dolioralia stage of $H$. nobilis was lower in all stocking densities compared to $H$. scabra (>12\%) reported by Abidin et al. (2019) at stocking densities of 1 , 1.5 and 2 larvae/ml. The lower percentage of $H$. nobilis larvae may be attributed to the late placement of settlement substrate during the transformation of the late auricularia to doliolaria as the larvae need settlement substrate as soon as the first the dolioralia appear. The stocking densities used in this study was optimal stocking density for many sea cucumber species, Agudo (2006) reported that the density of larvae in tanks is often between 0.3 and 1 larvae/ml. The optimum stocking density for $H$. scabra Versicolor and H. scabra was 0.75 and 1 larva/ml, respectively (Ivy et al., 2006). However, the lower optimum stocking density was recorded for Apostichopus japonicus, which were 0.1-0.2 larvae/ml, 0.3-0.4 larvae/ $\mathrm{ml}$, and 0.5 larvae/ml (Sun and Li, 2012). Asha and Diwakar 
(2013) also stated that the species-wise variations in the size of auricularia larvae leads to the difference in the optimum stocking density for the larval rearing. At high stocking densities. Large larvae may accumulate at high stocking densities, causing high mortality (Tuwo and Tresnati, 2015). In a $1 \mathrm{~m}^{3}$ filled with $750 \mathrm{I}$ of water, 0.3 million auricularia can be reared (James, 2004). Lower stocking density may cause an unnecessary waste of space and not efficient for the mass seed production of sea cucumber through hatchery system.

\section{Conclusion}

$H$. nobilis has been successfully induced to spawn under captivity by using two methods, thermal stimulation and the combination of thermal and algal stimulation. Thermal stimulation at ambient temperature $\pm 3-5^{\circ} \mathrm{C}$ was the simplest to induce spawning to the $H$. nobilis. Furthermore, higher growth, development, and survival rate of $H$. nobilis larvae during a pelagic stage were attained by feeding the larvae with mixed live microalgae ( $N$. oculata $+C$. muellerii $+I$. galbana at a stocking density of 300-600 larvae/l.

\section{Recommendation}

We suggest more research on water quality and control, best settlement substrate, optimal stocking density, and feeding regime. Nevertheless, consistent with preliminary observations, there is a high potential for commercial teat fish culture in tropical countries. Furthermore, utilization of cultured seed could even be crucial for $H$. nobilis aquaculture and restocking.

\section{Acknowledgements}

This research was supported by the National project "Research and development on artificial reproduction and growth out of teat fish sea cucumber Holothuria nobilis Selenka, 1867"-Project code: "NVQG-2017/13" which was funded by the Ministry of Science and Technology in Vietnam.

\section{References}

Abidin, N.A., Muhamad Shaleh, S.R., Ching, F.F., Othman, R., Manjaji-Matsumoto, M., Mustafa, S. and, Senoo, S., 2019. Appropriate Diet and Stocking Density for Sea Cucumber (Holothuria Scabra) Larvae Rearing. J. Phys. Conf. Ser.: 1358. DOI: 10.1088/1742-6596/1358/1/012015.

Agudo, N., 2006. Sandfish Hatchery Techniques. Secretariat of the Pacific Community, Noumea, New Caledonia: 44.

Al Rashdi, K.M., Eeckhaut, I., and Claereboudt, M.R., 2012. A manual on Hatchery of Sea cucumber Holothuria scabra in the Sultanate of Oman. Ministry of Agriculture and Fisheries Wealth, Aquaculture Centre, Muscat, Sultanate of Oman: 20

Arnold Rakaj, Alessandra Fianchini, Paola Boncagni, Alessandro Lovatelli, Michele Scardi, Stefano Cataudella, 2018. Spawning and Rearing of Holothuria tubulosa: A new candidate for aquaculture in the Mediterranean region. Aquaculture Research 49(1): 55768. DOI: $10.1111 /$ are.13487.

Arnold Rakaj, Alessandra Fianchini, Paola Boncagni, Michele Scardi, Stefano Cataudella 2019. Artificial reproduction of Holothuria polii: A new candidate for Aquaculture. Aquaculture 498:444-53. DOI: 10.1016/j.aquaculture.2018.08.060.

Asha, P. and Muthiah, P., 2002. Spawning and Larval Rearing of Sea Cucumber: Holothuria (Theelothuria) spinifera Theel. SPC Beche de mer Information Bulletin 16): 1115.

Asha, P. S. and Muthiah, P., 2006. Effects of Single and Combined Microalgae on Larval Growth, Development and Survival of the Commercial Sea Cucumber Holothuria spinifera Theel.: 113-18. DOI: 10.1111/j.1365-2109.2005.01396.x

Asha, P. S., and Diwakar, K., 2013. Effect of stocking density on the hatching rate, larval and early juvenile rearing of edible Sea cucumber Holothuria scabra (Jaeger, 1883). Indian Journal of Marine Sciences 42 (2): 191-95. DOI: 10.1016/j.aquaculture.2005.04.075. 
Asha, P. S., and Muthiah, P., 2005. Effects of Temperature, Salinity and PH on Larval Growth, Survival and Development of the Sea Cucumber Holothuria Spinifera Theel. Aquaculture 250(3-4): 823-29. DOI: 10.1016/j.aquaculture.2005.04.075.

Battaglene, S.C., 1999. Culture of Tropical Sea Cucumbers for Stock Restoration and Enhancement. ICLARM contribution 22(4): 4-11. https://www.cabi.org/ISC/abstract/20000107875

Bruckner, A. W., Johnson, K. A. and Field, J.D., 2003. Conservation Strategies for Sea Cucumbers: Can cites Appendix II Listing Promote Sustainable International Trade? SPC Beche-de-mer Information Bulletin (18): 24-33.

Dabbagh, A., Mohammad, R., Sedaghat, H. and Ehsan K., 2011. Breeding and Larval Rearing of the Sea Cucumber Holothuria leucospilota Brandt (Holothuria vegabunda Selenka) from the Northern Persian Gulf, Iran. SPC Beche-de-mer Information Bulletin (31): 35-38.

Dinh, C. H., 2017. General Description of the Study of Sea Cucumber Fisheries, Utilization and Trade in Vietnam. Research Institute for Marine Fisheries (RMIF):10-11

DOI: 10.12714/egejfas.2018.35.4.03

Domínguez-Godino J. A. and González-Wangüemert, M., 2019. Holothuria arguinensis: A new Sea Cucumber species for aquaculture. SPC Beche-de-mer Information Bulletin (39):60-64.

Domínguez-Godino, J. A. and Mercedes González-Wangüemert, M., 2018. Breeding and Larval Development of Holothuria mammata, a New Target Species for Aquaculture. Aquaculture Research 49(4): 1430-40. DOI: 10.1111/are.13597

Fernandez, C. and Charles F. B., 1998. Evaluating artificial diets for small Paracentrotus lividus (Echinodermata: Echinoidea). Echinoderms: 651-57.

Günay, D., Mustafa T. and Dilek E., 2018. Effects of various stocking densities on hatching and survival rates of sea cucumber Holothuria tubulosa, Eggs (Gmelin, 1788). Journal of Fisheries and Aquatic Sciences 35(4): 381-86.

I R Hudson, B D Wigham, M Solan, R Rosenberg., 2005. Feeding behaviour of deepsea dwelling holothurians: Inferences from a laboratory investigation of shallow fjordic species. Journal of Marine Systems, 57(3-4): 201-218. DOI: 10.1016/j.jmarsys.2005.02.004

Ivy, G. and Giraspy, D.A.B., 2006. Development of large-scale hatchery production techniques for the commercially important sea cucumber Holothuria scabra versicolor (Conand, 1986) in Queensland, Australia. Beche-de-mer information bulletin, (24): 28-34. James, D., 2004. Captive Breeding of the Sea Cucumber, Holothuria scabra, from India. Aquaculture Advances: 385-95.

Kinch, J.; Purcell, S.; Uthicke, S.; Friedman, K. 2008. Population status, fisheries and trade of sea cucumbers in the Western Central Pacific. In V. Toral-Granda, A. Lovatelli and M. Vasconcellos. Sea cucumbers. A global review of fisheries and trade. FAO Fisheries and Aquaculture Technical Paper. No. 516. Rome, FAO. pp. 7-55.

Laxminarayana, A., 2005. Induced Spawning and Larval Rearing of the Sea Cucumbers, Bohadschia marmorata and Holothuria atra in Mauritius. Fisheries Research 48-52.

Maria del Mar Otero Villanueva 2005. Stock Assessment of Sea Cucumbers from Phu Quoc, Vietnam. Spanish Agency for International Cooperation: 1-16. https://ruffordorg.s3.amazonaws.com/media/project_reports/24.08.03\%20Detailed\%20F inal\%20Report.pdf

Mazlan, N. and Hashim, R., 2015. Spawning induction and larval rearing of the Sea Cucumber Holothuria scabra in Malaysia, SPC Beche-de-mer Information Bulletin \#35: 3236.

Morgan, A. D., 2001. The effect of food availability on early growth, development and survival of the Sea Cucumber Holothuria scabra (Echinodermata: Holothuroidea). SPC Beche-de-mer Information Bulletin (14): 6-12.

Muthiga, N. A., Kawaka, J. A. and Ndirangu, S., 2009. The Timing and Reproductive Output of the Commercial Sea Cucumber Holothuria Scabra on the Kenyan Coast. Estuarine, Coastal and Shelf Science 84(3): 353-60. DOI: 10.1016/j.ecss.2009.04.011. 
Nathalie Marquet, Chantal Conand, Deborah M. Power, Adelino V.M. Canário, Mercedes González-Wangüemert ., 2017. Sea Cucumbers, Holothuria arguinensis and $H$. mammata, from the Southern Iberian Peninsula: Variation in reproductive activity between populations from different habitats. Fisheries Research 191: 120-30. DOI: 10.1016/j.fishres.2017.03.007

Nguyen D. Q. Duy,. 2017. Developing Hatchery Culture of the Tropical Sea Cucumber, Holothuria Scabra, and using micro-Algae concentrates. PhD Thesis, James Cook University. DOI: $10.4225 / 28 / 5 a f a 6 e 76 b 9100$

P.A.D. Ajith Kumara, J.S. Jayanatha, J. Pushpakumara, W. Bandara and D.C.T. Dissanayake ., 2013. Artificial Breeding and Larval Rearing of Three Tropical Sea Cucumber Species - Holothuria scabra, Pseudocolochirus Violaceus and Colochirus quadrangularis in Sri Lanka: 30-37.

Purcell, S. W., Cathy A. Hair and David J. Milis, 2012. Sea Cucumber Culture, Farming and Sea Ranching in the Tropics: Progress, Problems and Opportunities. Aquaculture 368369: 68-81. DOI: 10.1016/j.aquaculture.2012.08.053.

Ramofafia, C., Byrne, M. and Battaglene, S., 2002. Reproduction of the Commercial Sea Cucumber Holothuria Scabra (Echinodermata: Holothuroidea) in the Solomon Islands." Marine Biology 142(2): 281-88. DOI: 10.1007/s00227-022-0947-x.

Razek, F.A., Rahman, S.H.A., Moussa, R.M., Mena, M.H. and El-Gamal, M.M., 2012. Captive Spawning of Holothuria arenicola (Semper, 1868) from Egyptian Mediterranean Coast. Asian J. Biol. Sci. 5 (8): 425-431. DOI: 10.3923/ajbs.2012.425.431.

Serang, A.M., Santi, P.T.R. and Pitjont T., 2016. Effect of different stocking densities on growth and survival rates of Sea cucumber Holothuria scabra seedlings. Aquaculture Indonesiana 17(1): 30-34. DOI: 10.21534/ai.v17i1.44.

Slater, M.J., Andrew J. and Alexander G.C., 2009. The use of the waste from Greenlipped Mussels as a food source for Juvenile Sea cucumber, Australostichopus mollis. Aquaculture 292(3-4): 219-24. DOI: 10.21534/ai.v17i1.44.

Sun, X. and Qi Li., 2012. Effects of temporary starvation on larval growth, survival and development of the Sea cucumber Apostichopus japonicus. Marine Biology Research 8(8): 771-77. DOI: $10.1080 / 17451000.2012 .676186$.

Tuwo, A. and Tresnati, J., 2015. Echinoderm Aquaculture Sea Cucumber Farming in Southeast Asia (Malaysia, Philippines, Indonesia, Vietnam) Echinoderm Aquaculture: 331352, In: Echinoderm Aquacuture (eds): Brown N.P. Eddv.S.D. DOI: 10.1002/9781119005810.ch15.

Wen, J., Hu C. and Sigang F., 2010. Chemical composition and nutritional quality of Sea cucumbers. Journal of the Science of Food and Agriculture 90(14): 2469-74. DOI: 10.1002/jsfa.4108.

WenHuang, Da Huo, Zonghe Yu, Chunhua Ren, Xiao Jiang, Peng Luo, Ting Chen, Chaoqun Hu., 2018. Spawning, Larval Development and Juvenile growth of the tropical Sea Cucumber Holothuria Leucospilota. Aquaculture (488): 22-29. DOI: 10.1016/j.aquaculture.2018.01.013. 